\title{
1 Assessing the hydrological effects of land-use changes on a catchment using the Markov
}

\section{Chain and WetSpa models}

3 Ataollah Kavian $^{\mathrm{a}^{*}}$, Narges Javidan ${ }^{\mathrm{a}}$, Abdolreza Bahrehmand ${ }^{\mathrm{b}}$, Yeboah Gyasi-Agyei ${ }^{\mathrm{c}}$, Zeinab Hazbavi ${ }^{\mathrm{d}}$,

4 Jesús Rodrigo-Comino ${ }^{\text {e.f }}$

5 aSari Agricultural Sciences and Natural Resources University, Sari, Iran. a.kavian@sanru.ac.ir;

$6 \quad$ nargesjavidan20@gmail.com

$7 \quad$ b Gorgan University of Agricultural Sciences and Natural resources, Gorgan, Iran. abdolreza.bahremand@yahoo.com

$8{ }^{\mathrm{c}}$ School of Engineering and Technology, Central Queensland University, Rockhampton, Australia. y.gyasi-

9 agyei@cqu.edu.au

$10{ }^{\mathrm{d}}$ Department of Natural Resources, Faculty of Agriculture and Natural Resources and Member of Watershed

11 Management Research Center, University of Mohaghegh Ardabili, Iran. z.hazbavi@uma.ac.ir

12 ePhysical Geography, Trier University, 54286 Trier, Germany. rodrigo-comino@uma.es

13 fSoil Erosion and Degradation Research Group, Department of Geography, Valencia University, Blasco Ibàñez, 28,

1446010 Valencia, Spain. rodrigo-comino@uma.es

15

\section{*CONTACT}

17 Ataollah Kavian, Department of Watershed Management, Sari Agricultural Sciences and Natural Resources

18 University (SANRU), Sari, Mazandaran, Iran, 4844174111. Email: a.kavian@sanru.ac.ir

19

20

21

22

23

24

25

26

27

28

29

30

31 
33 Predicting the effects of land use (LU) changes and hydrological processes on a rapidly urbanised

34 catchment using the Markov Chain and WetSpa models is the main objective of this research.

35 Hourly hydrometeorological data for 2001-2016, land use maps, a DEM and soil texture were used as inputs into the models. The simulation results verified some negative impacts of LU changes such as increases in peak discharge and flow velocity from 2001 to 2032 by $57.1 \%$ and $39.4 \%$, respectively. Additionally, the time of concentration decreased from $6 \mathrm{~h}$ in 2001 to $5 \mathrm{~h}$ in 2016 and to $4 \mathrm{~h}$ in 2032 . Surface runoff recorded the highest increases by $48.4 \%$ and $83.9 \%$, respectively, in 2016 and 2032, compared to 2001. We concluded that the combination of both models is an appropriate tool for predicting the possible effects of LU changes on different hydrologic features,

42 which are vital information for land managers.

44 KEYWORDS: catchment response; human impact; interactive relations; Markov Chain;

45 WetSpa.

\section{I INTRODUCTION}

Deforestation, agriculture development, and urban growth are recognised as major land use and land cover (LULC) changes worldwide, especially in developing countries (Bahremand et al. 50 2007, Kharazmi et al. 2018, Hazbavi et al. 2019). LULC changes strongly affect the hydrological 51 processes (Chen and Yu 2015, Wang et al. 2015, Cerdà et al. 2019). Impervious surfaces in urban 52 areas limit the infiltration of water into the soils resulting in increased surface runoff, and having 53 a reduction in surface roughness shortens the overland flow detention time (Bosmans et al. 2017, 
Hazbavi 2018). This can drastically affect water quality and storage (Kavian et al., 2018, Vargas-

55 Pineda et al., 2020) and vegetation status or soil properties (Jafarian \& Kavian, 2013).

For decades, different hydrological models, ranging from physical to empirical types (e.g.,

57 such as Soil and Water Assessment Tool (SWAT), Water Erosion Prediction Project (WEPP), and

58 Runoff Routing Model (RORB) have been used to estimate runoff (Memarian et al. 2014, Khoi

59 and Suetsugi 2014, Chen and Yu 2015, Tan et al. 2015). Additionally, some models like Water

60 and Energy Transfer between Soil, Plant and Atmosphere (WetSpa) can combine the hydrological

61 processes with land use (LU) change detection techniques (Bahremand et al. 2006, 2007,

62 Albhaisi et al. 2013, Wang and Chen 2019).

The high potential of WetSpa in predicting spatial hydrological components of different conditions have been well documented (Bahremand et al. 2006, 2007, Tavakoli and De Smedt 2013, Karimi et al. 2016). Major advantages of the WetSpa model include the use of a GIS

(Geographic Information System) platform, based on physically-based processes, incorporating

67 distributed hydrological modelling and requiring a few parameters for calibration (Hosseini and Ashraf 2015, Abdollahi et al. 2018).

Integration of the effect of spatiotemporal land cover changes on the ecosystem with

71 processes in catchment hydrologic systems is well documented too (e.g., (Kavian et al., 2017,

72 Wang et al., 2013; Minea et al., 2019, Saint-Laurent et al., 2019). In this regard, the Markov Chain

73 model has been widely used to predict future land cover changes (Keshtkar and Voigt 2016, Hamad

74 et al. 2018, Gebremedhin 2019). This model is recognised as the most widely used for LU

75 predictions in different regions due to its dynamic considerations in LULC in terms of both spatial 
and temporal scales (Gebremedhin 2019), as well as being precise and dependable (Hamad et al.

77 2018).

In the scientific literature, there are many investigations that assess LU change effects on hydrological regimes. For example, Nejadhashemi et al. (2011) studied the LU change effects on hydrologic responses in the agricultural regions of Michigan and Wisconsin, USA. In Saudi Arabia, Mahmoud and Alazba (2015) assessed the spatial changes of surface runoff as a result of LU change in the Al-Baha region. They used the Soil Conservation Service Curve Number (SCSCN) method combined with Markov Chain analysis. Zhang et al. (2016) also investigated the hydrological impacts of LU change and climate variability during two periods of 1995-2014 and 2015-2024 in China. In this study, LU models of Markov Chain and Dyna-CLUE were combined with the SWAT model. Hamad et al. (2018) predicted the LULC changes for 2023 under two scenarios of "Iraq under siege" and "Iraq after siege". They used LU maps of 1993, 1998, 2003, 2008 and 2017 for the Cellular Automata (CA)-Markov Chain model.

This type of research is generally not common in rapidly developing countries like Iran that are experiencing drastic urbanisation processes. In Iran, Mohammady et al. (2018) modelled the 91 hydrological effects of LU change of the Baghsalian catchment in the Golestan Province. The LU 92 changes in terms of conversion of forest and rangeland to agriculture and urban settlement in this catchment increased surface and sub-surface runoff. Recently, Gebremedhin (2019) evaluated the spatiotemporal variation of LULC change in northern Ethiopia. They concluded that conducting such a study could help to formulate sound policies and strategies concerning sustainable 96 development. With the ever-changing climate, it is imperative that more research is conducted on 97 the topic in developing countries (van der Bank \& Karsten, 2020, Gondhalekar \& Ramsauer, 98 2016). 
Understanding the present and future LULC changes, and their impacts on the hydrological

100

101

102

103

104

105

106

107

108

109

110

111

112

113

114

115

116

117

118

119

120

121

processes, could be vital for natural environment conservation in rapidly developing countries, especially at the catchment scale (e.g., Visessri and McIntyre 2016, Marhaento et al. 2018), thus preventing irreparable land degradation over the short to medium term (Memarian et al. 2014). Therefore, the present research is formulated for the Ziarat Catchment, Golestan Province, northern Iran. The specific objectives of this study are to a) assess the LU changes during the 20012016 period; b) predict the future LU changes during 2001-2032 using a Markov Chain method; and c) assess the changes in hydrological processes caused by LU changes using the WetSpa model. In different parts of the Ziarat Catchment, the rapid urbanisation has resulted in unusual LU changes that have influenced the water resources to a large degree. In this study, the main novelty is the combination of a predictive model such as the Markov Chain method and the WetSpa model to investigate LU changes for the first time for a rapidly urbanising area in a developing country. Using the results of this study, water managers and policymakers could be more capable of making proper decisions to mitigate flood-related problems including biodiversity losses and pollutant transport.

\section{MATERIALS AND METHODS}

\subsection{STUDY AREA}

The Ziarat Catchment (9580 ha) is situated within the mountainous area of the southern part of Golestan Province, Iran (Figure 1). It lies between longitudes of 54 $20^{\prime} 13^{\prime \prime}$ and $54^{\circ} 35^{\prime} 55^{\prime \prime} \mathrm{E}$ and latitudes of $36^{\circ} 35^{\prime} 58^{\prime \prime}$ and $36^{\circ} 47^{\prime} 11^{\prime \prime} \mathrm{N}$. The elevation of the study catchment varies between 491 and 3,027 m. It has steep hillslopes with an average slope of about $41.4 \%$, suggesting 
122 significant erosive power of generated runoff and its capability to transport sediments and debris

123 downstream. Although the catchment receives some snow in winter, its hydrology is primarily

124 driven by rainfall which contributes about $30 \%$ of the domestic water supply of Gorgan City.

125

126

127 The climate of the region is warm and temperate, falling under class Csa of the Köppen-Geiger 128

129

130

131

132

133

134 135

136

137

138

139

140

141

142

143

144

$<<$ Figure $1>>$

method (Peel et al. 2007). It experiences an average annual, monthly maximum (March) and monthly minimum (August) precipitations of 550, 90 and $18 \mathrm{~mm}$, respectively. For the temperature, the average is $17.8^{\circ} \mathrm{C}$, with the maximum occurring in July $\left(28^{\circ} \mathrm{C}\right)$ and minimum in January $\left(8^{\circ} \mathrm{C}\right)$. The highly erodible formation of Shemshak and Gorgan Schists form approximately $36 \%$ of the catchment. Different erosion facies consisting of falls, debris, and streamside erosion manifest in this catchment (Kornejady et al. 2017). The catchment has diverse LULC including forests, rangelands, farmlands, and urban areas. In recent years, this catchment has been subjected to environmental risks because of tourist facilities and settlement developments. This is particularly the case for the village of Ziarat, with about 2000 inhabitants, which is an important tourist destination in Golestan Province (Zamani et al. 2012). Because of the rapid conversion of forest lands and farms to residential areas (Figure 2), it is hypothesised that runoff volume and flood peak will increase with negative consequences on social, economic and financial fronts.

$<<$ Figure $2>>$

\subsection{Data collection and processing}

Figure 3 shows a flowchart explaining the methodological procedure. In the ensuing sections, the different parts of the modelling process are explained in detail. 
147 The hydrometeorological data were obtained from the Meteorological Organization of Golestan

148 Province (http://portal.golestanmet.ir/) and the Golestan Regional Water Authority 149 (http://www.gsrw.ir/?1=EN) and the stations are presented in Table 1 . The data consists of 16 years 150 (2001-2016) of hourly precipitation data from two stations (Abgir, ID: 12-212 and Naharkhoran, 151 ID: 12-024), hourly temperature and evapotranspiration from the Abgir Station (ID: 12-215), and 152 hourly discharge data from Naharkhoran Station (12-043).

154 In Figure 4 are presented the maps of the digital elevation model (DEM) and soil texture used as 155 inputs to the WetSpa model. The 30-m grid size DEM of the Ziarat Catchment was derived from 156 the 1:50,000 topography map of Iran while the 30-m grid size soil texture map was collected from 157 the Forests, Ranges and Watershed Management Organization of Iran. There are three soil texture 158 categories, namely sandy loam (SL), silty loam (SL) and clay loam (CL) in the study catchment.

The LU maps of 2001 and 2016 were based on the Landsat Satellite images (30-m spatial resolution) retrieved from USGS Landsat ETM/TM satellites (http://glovis.usgs.gov/) and initially 162 they were interpreted visually. Then, the pre-processing requirements including atmospheric and 163 radiometric corrections were carried out. This was followed by the application of the maximum 164 likelihood classification (MLC) to generate the final LU maps of 2001 and 2016 (Karan and 165 Samadder 2016). The ArcGIS 10.3 Software (ESRI, USA) was used as the primary environment 166 to prepare all the maps. However, the prepared maps in ArcGIS were imported into ArcView 
167 Software for further processing as required by the WetSpa model. Note that the WetSpa model is

168 supported and implemented entirely within the ArcView environment (Liu and De Smedt 2004).

\subsection{Land-use change assessment}

171 Transition probabilities required by the Markov Chain landscape prediction model (Weng 2002,

172 Keshtkar and Voigt 2016) were derived from the 2001 to 2016 time series of the LU maps.

173 According to Tang et al. (2007), all LU spatial transition models could be explained by the

174 following matrix equation:

$$
V_{t+1}=V_{t} \times \mathrm{P}
$$

175 where $V_{t+1}$ and $V_{t}$ are vectors consisting of fractions of each LU type at times of $t+1$ and $t$,

176 respectively. The square matrix $\mathrm{P}$ is the transition probability $P(i, j)$ from landscape $i$ to $j$ during 177 the study period. Here, the $P(i, j)$ in $k$ steps is calculated as (Anderson and Goodman, 1957; Tang 178 et al., 2007):

$$
\begin{aligned}
& P_{i, j}=\sum_{k=1}^{k} \frac{P_{m}(i, j)}{k n_{m}} \\
& P_{m}(i, j)={ }^{N_{(i, j)}} / \sum_{j=1}^{n} n_{i j}
\end{aligned}
$$

179 where $N(i, j)$ is the observed data (i.e., vectors of each LU type) during the transition, $n_{i j}$ is the number of years between time steps $i$ and $j$, and $\mathrm{n}_{\mathrm{m}}$ is the total number of years (Tang et al. 2007).

181 It was assumed that the LU change is stochastic. It is also supposed that the transition probability 182 matrix (P) stays constant in consecutive periods (Chakraborty et al. 1995). The spatial transition 183 probabilities, when more than one step is needed, are obtained from the elements of $P_{i j}$. The 184 primary limitations of Markov Chain transition probability-based models for LULC change 
185 186 187 188 189 190 191 192 193 194 195 196 197 198 199 200 201 202 203 204 205 206 207

analysis include i) the assumption of spatial independence of transitions; and ii) the difficulty of ascribing causality within the model, i.e., the transition probabilities are often derived empirically from multi-temporal maps with no description of the process (Baker, 1989). Another limitation of this model is the division method of small regions, in which cells with the same land-use class transit to other land use classes according to the same transition probability (Yang et al., 2014). Also, the main limitation of the Markov Cellular Automata model is that it assumes that the factors of change in the past remain the same in the future (Yagoub et al., 2014).

For the current research, three scenarios of 2001, 2016 and 2032 were evaluated. Hypothetically, the Markov Chain model assumes that the transition possibility is spatially independent (Brown et al. 2000). Due to the effect of neighbouring cells, the forthcoming tendency of a specific pixel would not be a simple function of its present status which is disregarded in the stand-alone Markov Chain model (Tang et al., 2007).

In this paper, the Markov Chain model was applied based on the classified LU map of 2001 to estimate the future LU change (i.e., 2032). To validate the model, we first estimated the LU map of 2016 using the LU maps of 2001 and 2016 as inputs to the Markov Chain model. Then, the obtained results were compared with the LU map of 2016 which was extracted from Landsat image analysis. The LU maps which were generated by Landsat image analysis (i.e., 2001 and 2016) and that predicted by the Markov Chain model (i.e., 2032) were applied as inputs into the WetSpa model. Three indices of overall, user and producer accuracies, as well as the Kappa statistic, were finally derived for validation of the results of the LU classes of 2001 and 2016 (Zakerinejad and Maerker 2015). For the accuracy assessment, we used the information obtained from the field observations and photo-interpretations using Google earth images. 


\subsection{The WetSpa model}

209 The WetSpa model was initially developed by Wang et al. (1996) in the context of water and energy transfer between soil, plants and the atmosphere. This spatially distributed physically based model has been adapted for flood prediction (De Smedt et al. 2000, Liu et al. 2003, 2004, Liu and De Smedt 2005). A combination of empirical as well as physical relations was employed to

214 precipitation, evapotranspiration, depression storage, interception, infiltration, percolation, water

215 balance and flow components of surface runoff, interflow, and groundwater flow were considered

216 in the model. A combination of a segregated water balance for the vegetated, bare-soil, and the 217 impermeable portion of each raster cell, and open water is considered as the total water balance 218 for each cell (Zeinivand 2015, Karimi et al. 2016). The model simulates the spatial pattern of 219 hydrological components at the catchment scale and predicts peak discharges and hydrographs for 220 the stream network.

A moisture-related modified rational method with potential runoff coefficient was applied 222 for excess rainfall calculation (Liu and De Smedt 2004, Bahremand et al. 2006, Albhaisi et al. 223 2013). These calculations were done according to land cover, soil type, slope, the magnitude of 224 rainfall, and the antecedent soil moisture as documented in previous research (Liu and De Smedt 225 2004, Bahremand et al. 2006, Albhaisi et al. 2013).

226 The interflow and percolation are assumed to be gravity-driven in the model (Famiglietti 227 and Wood 1994). The percolation out of the root zone is associated with the hydraulic conductivity 228 at effective saturation (Eagleson 1978). It is assumed that the interflow occurs in the root zone 229 after percolation when the field capacity is less than the soil moisture. A kinematic wave 230 approximation and Darcy's law were applied to estimate the amount of interflow produced from 
231 each cell as a function of the hydraulic conductivity, slope angle, the root depth, and the moisture 232 content (Liu and De Smedt 2004).

The WetSpa model is made of a simple structure so that evapotranspiration, excess runoff, 234 interflow, percolation and infiltration are calculated pointwise (Liu and De Smedt 2005). The 235 routing of channel flow and excess runoff is carried out using the diffusive wave approximation 236 of the St. Venant equation given as (Bahremand et al. 2006):

$$
\frac{\partial Q}{\partial t}=d \frac{\partial^{2} Q}{\partial x^{2}}-c \frac{\partial Q}{\partial x}
$$

237 where $Q\left[\mathrm{~L}^{3} \mathrm{~T}^{-1}\right]$ is the discharge at time $t[\mathrm{~T}], x[\mathrm{~L}]$ is the distance along the flow direction, $d\left[\mathrm{~L}^{2} \mathrm{~T}^{-}\right.$

$\left.238{ }^{1}\right]$ is the dispersion coefficient and $c\left[\mathrm{LT}^{-1}\right]$ is the location-dependent kinematic wave celerity.

239 Parameters $c$ and $d$ could be predicted as $c=(5 / 3) v$ and $d=(v \mathrm{H}) /\left(2 \mathrm{~S}_{0}\right)$. The necessary prerequisites 240 were also fulfilled before applying this equation as recommended by Henderson (1966). Here, $v$ $241\left[\mathrm{LT}^{-1}\right]$ and $\mathrm{H}[\mathrm{L}]$ are respectively the flow velocity and hydraulic radius (or flow depth average). $242 \mathrm{H}[\mathrm{L}]$ is defined as (Molnar and Ramírez 1998):

$$
H=a_{p}\left(A_{i}\right)^{b_{p}}
$$

243 where $A_{i}\left[\mathrm{~L}^{2}\right]$ is the upstream drainage area of the cell. The constant network parameter of $\mathrm{a}_{\mathrm{p}}[-]$ 244 and the geometry scaling exponent of $b_{p}[-]$ could also be calculated based on the catchment 245 characteristics, both depending on the discharge frequency (Liu et al. 2003). The spatial 246 distribution of the soil, LU and topographic properties within the study area were modelled on a 247 small GIS-derived sub-catchment scale (Liu and De Smedt 2004, 2005).

248 Some other limitations of the WetSpa model are (Liu and De Smedt 2004): i) the defined LU 249 category groupings can be ambiguous with some uses potentially aligning with several identifiable 250 categories or even not aligning with any category; ii) different extensions of the software or input 251 data with different resolution can generate different results; iii) 30x30 m of resolution cannot 
252 distinguish some elements such as roads, bridges or houses; and iv) the spatial distribution of the

253 groundwater table, as well as its variation during the simulation periods, cannot be predicted.

\subsection{Gridded model data input}

A 30-m grid size DEM was used to extract the hydrologic and topographic features. For this research, two support area thresholds of 100 and 1000 cells were used to define the stream network and the 72 sub-catchments, respectively. A minimum slope threshold value of $0.01 \%$ was considered to deal with the flat areas or zero inclination in the area (Liu and De Smedt 2004; Bahremand et al. 2007).

The exceedance probability of 0.5 with a two-year return period of flow depth was used to produce the hydraulic radius grid. Correspondingly, the average hydraulic radius of 0.005 and 1.5

263 (m) resulted in the upland cells and main river outlet, respectively. In the next step, the reclassification of grid layers of soil hydraulic conductivity, residual moisture, plant-wilting point, porosity, pore size distribution index, and field capacity was done based on the grid of the soil texture layer by means of an attribute lookup table (Liu and De Smedt 2004, Bahremand et al.

267 2007). According to the WetSpa requirements, the grid of LU was also used as a basis for reclassification of layers of interception storage capacity, root depth, and Manning's roughness coefficient. More information about the pedotransfer functions used and the look-up tables is available in Rawls et al. (1983), Rowe (1983), Cosby et al. (1984) and Liu and De Smedt (2004).

271 The Manning's coefficients of the lowest and the highest stream order grids of 0.055 and 0.025

$272 \mathrm{sm}^{-1 / 3}$ were used as the basis for linear interpolation of the Manning's coefficient for the channels

273 (Liu et al. 2004, Bahremand et al. 2007). The combination of LU, DEM and soil texture were used 
274

275

276

277

278

279

280

281

282

283

284

285

286

287

288

289

290

291

292

293

294

295

296

to generate the maps as suggested by Liu and De Smedt (2004). The coefficient of potential runoff for the whole study catchment was set as 0.54 .

The appropriate grids of precipitation, temperature and potential evapotranspiration (PET) were determined with the help of geographical coordinates of the study stations and catchment boundary. The Thiessen polygon extension of the ArcView Spatial Analyst was applied to generate the precipitation map. Additionally, temperature and PET maps were depicted. To this end, the hourly values of temperature were generated by computing a sine curve from daily minimum and maximum (Liu and De Smedt 2004). The daily to hourly disaggregation of evaporation data were also done using a sine curve (Liu and De Smedt 2004). Finally, the flow velocity, mean travel time to the basin outlet and the standard deviation grids were determined according to the flow routing approach as explained above (Eqs. 4 and 5). These data enabled the calculation of the instantaneous unit hydrograph (IUH) of each grid cell and the catchment outlet (Albhaisi et al. 2013). The coefficient of groundwater flow recession was fitted according to the base flow of the observed hydrograph. In addition, the recession part was adjusted using an interflow scaling factor (Bahremand et al. 2007).

From the total study period from 2001 to 2016, two periods of 2001-2010 and 2011-2016 were considered for WetSpa model calibration and validation, respectively, using hourly hydrometeorological data. Manual calibration and parameter ESTimator (PEST) Software were used to set the optimal parameters (Karimi et al. 2016, Bahremand 2016). The 11 calibrated parameters are given in Table 2 .

For this research, the hourly hydrometeorological data (i.e., precipitation, temperature and evapotranspiration) of the 2001-2010 and 2011-2016 periods were used, respectively, for the 
calibration and validation steps of the WetSpa model. Both steps were carried out based only on the LU map of 2001. Then, the simulations of the calibrated WetSpa model were conducted using the hourly hydrometeorological data of the 2001-2016 period for the three LU maps of 2001, 2016 and 2032. The soil texture and DEM remained unchanged for the calibration, validation and simulation steps.

\subsection{Model evaluation}

304 Qualitative and quantitative assessments were used to evaluate the performance of the WetSpa 305 model in two steps of calibration and validation. In addition to the comparison of graphical results 306 of measured and predicted hydrographs, statistical analysis was also considered (Karimi et al. 307 2016). The Nash-Sutcliffe Efficiency (NSE) performance statistic was used to evaluate WetSpa simulations. NSE, a dimensionless coefficient with values ranging between $-\infty$ and 1 (perfect match), is expressed mathematically as (Nash and Sutcliffe 1970):

$$
\mathrm{NSE}=1-\frac{\sum_{1=1}^{\mathrm{n}}\left(\mathrm{Qs}_{\mathrm{i}}-\mathrm{Qo}_{\mathrm{i}}\right)^{2}}{\sum_{1=1}^{\mathrm{n}}\left(\mathrm{Qo}_{\mathrm{i}}-\overline{\mathrm{Qo}}\right)^{2}}
$$

where $Q_{s i}$ and $Q_{o i}$ are the simulated and measured flow components at time step $i$, respectively. In the simulated period, respectively.

The Kling-Gupta Efficiency (KGE) was also calculated to minimise the calibration problems 314 of the un-normalised mean square error component in NSE (Gupta et al. 2009).

$$
K G E=1-\sqrt{(r-1)^{2}+(\propto-1)^{2}+(\beta-1)^{2}}
$$

315 where $\alpha$ is the ratio of the standard deviation of $Q_{o}$ to that of $Q_{s}, \beta$ is the ratio of the average of $Q_{o}$ to that of $Q_{s}$, and $r$ is the Pearson correlation coefficient. Based on the obtained LU change maps, 317 model parameters were re-calculated, and the model was run to deliver the corresponding flows. 


\section{RESULTS}

\subsection{Land use change assessment}

321 The LU classification of 2001 and 2016 conducted using the maximum likelihood classification 322 (MLC) method within ENVI 4.8 Software is presented in Figure 5. The accuracy of each LU map 323 using the producer, user and overall accuracies, and the Kappa coefficient, are summarised in 324 Table 3. The accuracy of the Kappa statistic obtained is substantial $(>0.77)$ as stated by Landis and $325 \operatorname{Koch}(1977)$.

The validation step for the output of the Markov Chain Model was carried out by comparing the 2016 modelled output with the classified LU (Landsat images analysis) obtained for the same year, and overall spatial accuracy of $83 \%$ was obtained. The predicted LU change in 2032 which was projected using the Markov Chain Model is depicted in Figure 6. The changes in the total area from one LU type to another from 2016 to 2032 are summarised in the transition matrix in Table 4.

The area and percentage change in each LU class from 2001 to 2016 and from 2001 to 2032 are compared in Table 5. As seen in Table 5, the LU for 2001 was classified into four different 337 classes as urban (53 ha), forest (7562 ha), agriculture (594 ha) and rangeland (1371 ha). Forest 338 occupied the highest percentage of the total area in 2001. However, by 2016 the urban area had increased from 53 to 932 ha while forest and rangeland areas had decreased (with percentage changes of $11.5 \%$ and $0.5 \%$, respectively), with the forest area remaining the dominant LU. 
It is predicted that there would be an increase in urban area from 2001 to 2032 . The percentage

342

343

344 345

346

347

348

349

350

351

352

353

354

355

356

357

358

359

360

361

362

363

of change from 2001 to 2016 is very high for the settlements (1658.5\%) and the projected change from 2001 to 2032 is also very much elevated (4692.5\%). Rangeland, agriculture, and forest areas would decrease in 2032 by $22.1 \%, 56.7 \%$ and $33.3 \%$, respectively, compared to 2001 .

$<<$ Table 5 $>>$

\subsection{Hourly streamflow simulation}

The simulation results by application of LU change maps are compared to the observed hydrographs in Figure 7. Table 6 shows the comparison of changes in the simulated flow components to each LU change in the Ziarat Catchment.

$<<$ Figure $7>>$

$<<$ Table 6>>

The calibrated base temperature and degree-day coefficients, respectively, was $1{ }^{\circ} \mathrm{C}^{-1}$. The calibrated groundwater flow recession coefficient was $0.0025\left(\mathrm{~d}^{-1}\right)$ which gives a good estimation for all base flows. The model performance was also satisfactory because the NSE was 0.72 for the validation step and the modified NSE for high and low flows were, respectively, 0.81 and 0.82 .

The model outputs also showed that $15.9 \%, 83.5 \%$ and $83.7 \%$ of the precipitation was intercepted by plant canopy, infiltration and evapotranspiration, respectively. Additionally, 19.3\% became runoff, of which $17.5 \%$ recharged the groundwater reservoir, while $1.5 \%$ and $0.4 \%$ contributed to interflow, and a direct flow, respectively.

The model evaluation criteria of NSE of 0.68 and 0.72 was obtained for the direct discharges at calibration and validation steps, respectively. Additionally, the KGE of 0.73 and 0.79 were calculated for the calibration and validation periods. 


\subsection{Land-use change impacts on hydrological parameters and flow components}

366 Table 7 presents the results of the impact of LU changes on the hydrological parameters and flow 367 components. As mentioned previously, after calibration and validation of the WetSpa model, the 368 base inputs of this model were applied using the data from 2001 to 2016 for all three LU maps of 369 2001, 2016 and 2032. The average meteorological data were similarly considered for detection of changes in the hydrological parameters and the flow components under the effects of the three LU maps in the study time steps. The results indicate that urbanisation produced the highest change in 372 peak discharge by $26.9 \%$ and $57.1 \%$ in 2016 and 2032, respectively, compared with 2001 values.

373 The runoff coefficient value was projected to increase during the future, which caused an increase 374 in surface runoff and peak discharge. With increasing runoff coefficient and velocity, and 375 decreasing roughness, the time of concentration also decreased by $4.4 \%$ and $29.7 \%$ in 2016 and 376 2032, respectively. The flow velocity also experienced a modification influenced by the LU 377 changes, which generated an increase in runoff coefficient and a decrease in roughness.

378 Related to the flow components are surface runoff, interflow, and groundwater, which also 379 experience important changes (Table 7). As observed in Table 7, the surface runoff amount 380 increased with increasing urban areas. The surface runoff, interflow, and groundwater of 2001 381 were the lowest at 3.10, 16.00 and $305.90 \mathrm{~mm}$, respectively, but gradually increased and reached 382 the highest levels in the predicted model in 2032. There were gradual increases in groundwater 383 levels and interflow amounts due to the LU changes. 


\section{DISCUSSION}

388 The interaction and process of rainfall-runoff have been highly influenced by LU type and changes (Bahremand et al. 2006, Albhaisi et al. 2013, Guadie et al., 2020). The WetSpa model was calibrated to simulate hourly hydrographs of the Ziarat Catchment under different LU maps (2001, 2016, and 2032). The changes in the mean flow travel time and the standard deviation caused a change in the IUH of each cell and the total catchment. The simulated peak discharge for the 2001 LU was $3.01 \mathrm{~m}^{3} / \mathrm{s}$ and was $3.82 \mathrm{~m}^{3} / \mathrm{s}$ for the current (2016) LU, which means that the peak discharge has increased by $26.9 \%$, and for the future 2032 LU this would be $57.1 \%$. Additionally, the effects of LU change on flow components of surface, interflow and groundwater runoffs were also evaluated quantitatively from the model results. It was found that LU change from 2001 to 2032 resulted in increased surface and total runoffs by $83.9 \%$ and $6.3 \%$, respectively.

Increased discharge due to the growth of urbanisation has been reported by other researchers and, due to the climate change expectations, this dynamic would be even worse, further complicating land management plans (Higashino and Stefan, 2014, Miller and Hutchins, 2017). For example, Bahremand et al. (2007), simulating flows in the Margecany-Hornad Catchment, 402 Slovakia, observed a decrease in peak discharge by $12 \%$ that was caused by a $50 \%$ increase in 403 forest areas. Albhaisi et al. (2013) also found a systematic groundwater recharge increase due to 404 clearing of the non-native hillslope vegetation for the Upper Berg Catchment, South Africa. Niu 405 and Sivakumar (2014) reported increasing and decreasing flows, respectively, due to deforestation and afforestation for the East River catchment in South China.

407 Our results confirmed that the forest and agricultural areas decreased. Undeniably, the 408 vegetation cover, in the form of natural plants or agricultural fields, is one of the most important sources of water to the atmosphere (Prăvălie et al. 2019) and it deaccelerates runoff generation 
and river incisions (Bertalan et al. 2019). The detection of a strong relationship between an

411 increase in the water yield with a decrease in evapotranspiration also agrees with studies conducted

412 under different environmental circumstances, but all are highly affected by human activities (e.g.,

413 Wagner et al. 2013). A clear example that highlighted the impact of the LU changes caused by

414 substituting the vegetation with urban areas was reported in the Jinjiang Catchment of China (Lin

415 et al. 2015).

416 The expansion of urban areas and traffic is considered a key factor driving the decrease of the

417 vegetation areas in numerous catchments in mountainous areas (Rose and Peters 2001; Salesa and

418 Cerdà, 2019). For example, Hosseini et al. (2012) showed a progressive increase in surface runoff

$419(7.3 \%)$ and a decrease in the lateral flows (11.3\%). For our study, the groundwater is gradually

420 increased, but that may be due to the low value of evapotranspiration that was also very small

421 during the study periods. Solutions and alternatives must be developed, but undoubtedly, they

422 cannot be proposed without considering the opinion of stakeholders, inhabitants and policymakers

423 (Crossland et al., 2018, Petrakis et al., 2020, Rodrigo-Comino et al., in press)

424

425

\section{CONCLUSIONS}

426 A land use (LU) change assessment on hydrological processes was done for the Ziarat Catchment

427 in northern Iran. The LU changes during 2001 to 2016, including forest (-11.5\%), agricultural (-

$4282.2 \%)$ and grassland (-0.5\%) reductions as well as an urban land increase $(+16.6 \%)$, caused

429 significant changes in peak discharge $(+26.9 \%)$, time of concentration $(+4.4 \%)$, flow velocity $430(+24.6 \%)$, total runoff $(+2.6 \%)$, surface runoff $(+48.4 \%)$, interflow runoff $(+2.5 \%)$ and

431 groundwater runoff $(+2.2 \%)$. Scenario-based analysis of future LU changes to 2032 also showed 432 that the hydrology pattern of the Ziarat Catchment would be significantly affected. For the period 
433 2001-2032, the peak discharge, time of concentration, flow velocity, total runoff, surface runoff,

434 interflow runoff, and groundwater runoff were projected to increase by $57 \%, 29 \%, 39 \%, 6 \%, 84 \%$,

$4355 \%$ and $6 \%$, respectively. Because of the high capability of the Markov Chain and WetSpa models

436 in LU change and impact analysis, it is highly recommended to use these results for future

437 allocation of available water resources and effective management of the studied catchment.

438

439 Acknowledgements

440 The authors would like to thank the Regional Water Authority of Golestan Province for supporting

441 and making available the meteorological and flow discharge data. In addition, many thanks to

442 Forests, Ranges and Watershed Management Organization for their help to collect LU and soil 443 maps.

444

445 Disclosure statement

446 No potential conflict of interest was reported by the authors.

447

$448 \quad$ References

449 Abdollahi, K., Bazargan, A. and McKay, G., 2018. Water Balance Models in Environmental 450 Modeling. Springer International Publishing AG 2018, In C.M. Hussain (ed.), Handbook of 451 Environmental Materials Management, https://doi.org/10.1007/978-3-319-58538-3_119-1.

452 Albhaisi, M., Brendonck, L. and Batelaan, O., 2013. Predicted impacts of land use change on 453 groundwater recharge of the upper Berg Catchment, South Africa. Water, 39(2), 211-220.

454 Anderson, T.W. and Goodman, L.A., 1957. Statistical Inference About Markov Chains. The 455 Annals of Mathematical Statistics, 28(1), DOI: 10.1214/aoms/1177707039 
Bahremand, A., 2016. Advocating process modeling and de-emphasizing parameter estimation. Hydrological Earth System Science, 20, 1433-1445.

Bahremand, A., De Smedt, F., Corluy, J., Liu, Y.B., Poórová, J., Velcická, L. and Kunikova, E., 2006. Application of WetSpa model for assessing land use impacts on floods in the Margecany-Hornad Catchment, Slovakia. Water Science Technology, 53, 37-45.

Bahremand, A., De Smedt, F., Corluy, J., Liu, Y. B., Poorova, J., Velcicka, L. and Kunikova, E., 2007. WetSpa model application for assessing reforestation impacts on floods in MargecanyHornad Catchment, Slovakia. Water Resources and Management, 21, 1373-1391.

Bank, M. van der \& Karsten, J. (2020) Climate Change and South Africa: A Critical Analysis of the Earthlife Africa Johannesburg and Another v Minister of Energy and Others 65662/16 (2017) Case and the Drive for Concrete Climate Practices. Air, Soil and Water Research 13, 1178622119885372.

Bertalan, L., Rodrigo-Comino, J., Surian, N., Šulc Michalková, M., Kovács, Z., Szabó, S., Szabó, G., et al. (2019) Detailed assessment of spatial and temporal variations in river channel changes and meander evolution as a preliminary work for effective floodplain management. The example of Sajó River, Hungary. Journal of Environmental Management 248, 109277.

Bosmans, J.H.C., van Beek, L.P.H., Sutanudjaja, E.H. and Bierkens, M.F.P., 2017. Hydrological impacts of global land cover change and human water use. Hydrological Earth System Science, $21,5603-5626$.

Brown, D.G., Pijanowski, B.C. and Duh, J.D., 2000. Modelling the relationships between land use and land cover on private lands in the Upper Midwest, USA. Journal of Environmental Management, 59, 247-263. 
478 Cerdà, A., Ackermann, O., Terol, E., Rodrigo-Comino, J., 2019. Impact of Farmland 479 Abandonment on Water Resources and Soil Conservation in Citrus Plantations in Eastern Spain. Water 11, 824. https://doi.org/10.3390/w11040824

481 Chakraborty, U.K., Deb, K. and Chakraborty, M., 1995. Analysis of selection 482 algorithms: a Markov chain approach. Evolutionary Computation, 4, 133-167.

Chen, Y.R. and Yu, B., 2015. Impact assessment of climatic and land-use changes on flood runoff in southeast Queensland. Hydrological Sciences Journal, 60(10), 1759-1769.

485

486

487

488

489

490

491

492

493

494

495

496

497

498

499

500

Cosby, B.J., Hornberger, G.M., Clapp, R.B. and Ginn, T.R., 1984. A statistical exploration of the relationship of soil moisture characteristics to the physical properties of soils. Water Resources Research, 20, 682-690.

Crossland, M., Winowiecki, L. A., Pagella, T., Hadgu, K. \& Sinclair, F. (2018) Implications of variation in local perception of degradation and restoration processes for implementing land degradation neutrality. Environmental Development 28, 42-54.

De Smedt, F., Liu, Y.B. and Gebremeskel, S., 2000. Hydrological modeling on a catchment scale using GIS and remote sensed land use information. In: Risk Analysis II, Brebbia, C.A. (ed.), WTI Press, Boston, USA, 295-304.

Eagleson, P.S., 1978. Climate, soil, and vegetation, a simplified model of soil moisture movement in liquid phase. Water Resources Research, 14(5), 722-730.

Ebrahimian, A., Wilson, B.N. and Gulliver, J.S., 2016. Improved methods to estimate the effective impervious area in urban catchments using rainfall-runoff data. Journal of Hydrology, 536, $109-118$

Famiglietti, J.S. and Wood, E.F., 1994. Multiscale modeling of spatially variable water and energy balance processes. Water Resources Research, 30 (11), 3061-3078. 
501 Gebremedhin, M.A., 2019. Spatio-temporal water resource responses to land use land cover 502 change in semi-arid Opper Tekeze Basin, Northern Ethiopia. PhD Research Proposal, $503 \quad$ University of Twente, The Netherlands, $57 \mathrm{p}$.

504 Gondhalekar, D. \& Ramsauer, T. (2016) Nexus City: Operationalizing the urban Water-Energy505 Food Nexus for climate change adaptation in Munich, Germany. Urban Climate. $506 \quad$ doi:10.1016/j.uclim.2016.11.004

507 Guadie, M., Molla, E., Mekonnen, M. \& Cerdà, A. (2020) Effects of Soil Bund and Stone-Faced 508 Soil Bund on Soil Physicochemical Properties and Crop Yield Under Rain-Fed Conditions of 509 510 Northwest Ethiopia. Land 9(1), 13. doi:10.3390/land9010013

Gupta, H.V., Kling, H., Yilmaz, K.K. and Martinez, G.F., 2009. Decomposition of the mean squared error and NSE performance criteria: Implications for improving hydrological modelling. Journal of Hydrology, 377, 80-91.

513 Hamad, R. and Balzter, H., 2018. Predicting land use / land cover changes using a CA-Markov 514 model under two different scenarios. Sustainability, 10, 1-23.

Hazbavi, Z., 2018. Importance of geology and geomorphology in watershed health assessment. Agriculture \& Forestry, 64(4), 277-287.

517 Hazbavi, Z., Sadeghi, S.H.R., Gholamalifard, M., Davudirad, A.A., 2019. Watershed health assessment using pressure-state- response (PSR) framework. Land Degradation and Development, 1-17.

Henderson, F.M., 1966. Open Channel Flow, McMillan, New York, USA.

521 Higashino, M., Stefan, H.G., 2014. Hydro-climatic Change in Japan (1906-2005): Impacts of 522 Global Warming and Urbanization. Air, Soil and Water Research 7, ASWR.S13632. 
523 Hosseini, M, Ghafouri, A.M., Amin, M.S.M., Tabatabaei, M.R., Goodarzi, M. and Abde 524 Kolahchi, A., 2012. Effects of land use changes on water balance in Taleghan catchment, 525 Iran. Journal of Agricultural Science and Technology, 14 (5), 1161-1174.

526 Hosseini, M. and Ashraf, M.A., 2015. Effect of Land use changes on water balance and sediment 527 yield in Iran. Chapter 2, In: Application of the SWAT model for water components separation 528 in Iran. Springer Hydrogeology, 33-61.

529 Jafarian, Z. and Kavian, A. 2013. Effects of Land-Use Change on Soil Organic Carbon and 530 Nitrogen. Communications in Soil Science and Plant Analysis 44(1-4), 339-346.

531 Jinno, K., Tsutsumi, A., Alkaeed, O., Saita, S. and Berndtsson, R., 2009. Effects of land-use 532 change on groundwater recharge model parameters, Hydrological Sciences Journal, 54(2), $533 \quad 300-315$.

534 Karan, S.K. and Samadder, S.R., 2016. Accuracy of land use change detection using support vector 535 machine and maximum likelihood techniques for open-cast coal mining areas. Environment 536 and Monitoring Assessment, 188 (8), 486.

537 Karimi, H., Zeinivand, H., Tahmasebipour, N., Haghizadeh, A. and Miryaghoubzadeh, M., 2016. 538 Comparison of SRM and WetSpa models efficiency for snowmelt runoff 539 simulation. Environmental Earth Sciences, 75 (8); 190:356.

540 Kavian, A., Mohammadi, M., Gholami, L. \& Rodrigo-Comino, J. 2018. Assessment of the 541 Spatiotemporal Effects of Land Use Changes on Runoff and Nitrate Loads in the Talar River. $542 \quad$ Water 10(4), 445.

543 Kavian, A., Sabet, S. H., Solaimani, K. \& Jafari, B. 2017. Simulating the effects of land use 544 changes on soil erosion using RUSLE model. Geocarto International 32(1), 97-111. 
545

546

547

548

549

550

551

552

553

554

555

556

557

558

559

560

561

562

563

564

565

566

Keshtkar, H. and Voigt, W., 2016. A spatiotemporal analysis of landscape change using an integrated Markov chain and cellular automata models. Modeling Earth Systems and Environment, 2 (1), 1-13.

Kharazmi, R., Tavili, A., Rahdari, M.R., Chaban, L., Panidi, E., Rodrigo-Comino, J., 2018. Monitoring and assessment of seasonal land cover changes using remote sensing: a 30 -year (1987-2016) case study of Hamoun Wetland, Iran. Environmental Monitoring and Assessment 190, 356.

Khoi, D.N. and Suetsugi, T., 2014. Impact of climate and land-use changes on hydrological processes and sediment yield - a case study of the Be River catchment, Vietnam. Hydrological Sciences Journal, 59(5), 1095-1108.

Kornejady, A., Ownegh, M. and Bahremand, A., 2017. Landslide susceptibility assessment using maximum entropy model with two different data sampling methods. Catena, 152, 144-162.

Landis, J.R. and Koch, G.G., 1977. The measurement of observer agreement for categorical data. Biometrics, 159-174.

Lin, B., Chen, X., Yao, H., Chen, Y., Liu, M., Gao, L. and James, A.L., 2015. Analyses of land use change impacts on catchment runoff using different time indicators based on SWAT model. Ecological Indicators, 58, 55-63.

Liu, Y.B. and De Smedt, F., 2004. WetSpa extension, a GIS-based hydrologic model for flood prediction and watershed management. Brussels: Department of Hydrology and Hydraulic Engineering, Vrije Universiteit Brussel. 126 p.

Liu, Y.B. and De Smedt, F., 2005. Flood modeling for complex terrain using GIS and remote sensed information. Water Resource Management, 19, 605-624. 
Liu, Y.B., Gebremeskel, S. and De Smedt, F., 2003. A diffusive transport approach for flow routing in GIS-based flood modeling. Journal of Hydrology, 283, 91-106.

Mahmoud, S.H. and Alazba, A.A., 2015. Hydrological response to land cover changes and human activities in arid regions using a geographic information system and remote sensing. PLoS ONE, $10(4), 19 \mathrm{p}$.

Marhaento, H., Booij, M.J. and Hoekstra, A.Y., 2018. Hydrological response to future land-use change and climate change in a tropical catchment. Hydrological Sciences Journal, 63(9), $1368-1385$.

Memarian, H., Balasundram, S.K., Abbaspour, K.C., Talib, J.B., Boon Sung, C.T. and Sood, A.M., 2014. SWAT-based hydrological modelling of tropical land-use scenarios. Hydrological Science Journal, 59, 1808-1829.

Miller, J.D., Hutchins, M., 2017. The impacts of urbanisation and climate change on urban flooding and urban water quality: A review of the evidence concerning the United Kingdom. Journal of Hydrology: Regional Studies 12, 345-362.

Minea, G., Ioana-Toroimac, G. \& Moro, G. (2019) The dominant runoff processes on grassland versus bare soil hillslopes in a temperate environment - An experimental study. Journal of Hydrology and Hydromechanics 67, 8. doi:10.2478/johh-2019-0018

Mohammady, M., Moradi, H.R., Zeinivand, H., Temme, A.J.A.M., Yazdani, M.R. and Pourghasemi, H.R., 2018. Modeling and assessing the effects of land use changes on runoff generation with the CLUE-s and WetSpa models. Theoretical and Applied Climatology, 2018, $133,1-2,459-471$.

Molnar, P. and Ramírez, J.A., 1998. Energy dissipation theories and optimal channel characteristics of river networks. Water Resources Research, 34, 1809-1818. 
Muller, M.R. and Middleton, J., 1994, A Markov model of land-use change dynamics in the Niagara Region, Ontario, Canada. Landscape Ecology, 9, 151-157.

Nash, J. and Sutcliffe, J.V., 1970. River flow forecasting through conceptual models part I-a discussion of principles. Journal of Hydrology, 10, 282-290.

Nejadhashemi, A.P., Wardynski, B.J. and Munoz, J.D., 2011. Evaluating the impacts of land use changes on hydrologic responses in the agricultural regions of Michigan and Wisconsin. Hydrology and Earth System Sciences Discussions, 8, 3421-3468.

Niu, J. and Sivakumar, B., 2014. Study of runoff response to land use change in the East River basin in South China. Stochastic Environmental Research and Risk Assessment, 28, 857-865.

Nyenje, P.M. and Batelaan, O., 2009. Estimating the effects of climate change on groundwater recharge and baseflow in the Upper Ssezibwa Catchment, Uganda. Hydrological Sciences Journal, 54(4), 713-726.

Peel, M.C., Finlayson, B.L. and McMahon, T.A., 2007. Updated world map of the Köppen-Geiger climate classification. Hydrological Earth System Science, 11, 1633-1644.

Petrakis, R. E., Norman, L. M., Lysaght, O., Sherrouse, B. C., Semmens, D., Bagstad, K. J. \& Pritzlaff, R. 2020. Mapping Perceived Social Values to Support a Respondent-Defined Restoration Economy: Case Study in Southeastern Arizona, USA. Air, Soil and Water Research 13,1178622120913318 .

Prăvălie, R., Piticar, A., Rosea, B., SficaL, L., Bandoc, G., Tiscovschi, A. and Patriche, C., 2019. Spatio-temporal changes of the climatic water balance in Romania as a response to precipitation and reference evapotranspiration trends during 1961-2013. Catena, 172, 295-312.

Rawls, W.J., Brakensiek, D.L. and Saxton, K.E., 1983. Estimation of soil water properties. Transactions of the American Society of Agricultural Engineers, 25(5), 1316-1320. 
613 Rodrigo-Comino, J., Giménez-Morera, A., Panagos, P., Pourghasemi, H. R., Pulido, M. \& Cerdà, 614 A. In Press. The potential of straw mulch as a nature-based solution for soil erosion in olive 615 plantation treated with glyphosate: A biophysical and socioeconomic assessment. Land Degradation \& Development. doi:10.1002/1dr.3305

617

618

619

620

621

622

623

624

625

626

627

628

629

630

631

632

633

634

Rose, S. and Peters, N.E., 2001. Effects of urbanization on streamflow in the Atlanta area (Georgia, USA): a comparative hydrological approach. Hydrological Processes, 15, 1441-1457.

Rowe, L.K., 1983. Rainfall interception by an evergreen beech forest. Journal of Hydrology, 66, 143-158.

Saint-Laurent, D., Arsenault-Boucher, L. \& Berthelot, J.-S. (2019) Contrasting Effects of Flood Disturbance on Alluvial Soils and Riparian Tree Structure and Species Composition in Mixed Temperate Forests. Air, Soil and Water Research 12, 1178622119872773. doi:10.1177/1178622119872773

Salesa, D. and Cerdà, A. 2019. Four-year soil erosion rates in a running-mountain trail in eastern Iberian Peninsula. Geographical Research Letters 45(1), 309-331.

Tan, M.L., Ibrahim, A.L., Yusop, Z., Duan, Z. and Ling, L., 2015. Impacts of land-use and climate variability on hydrological components in the Johor River Basin, Malaysia. Hydrological Sciences Journal, 60(5), 873-889

Tang, J., Wang, L. and Yao, Z., 2007. Spatio-temporal urban landscape change analysis using the Markov chain model and a modified genetic algorithm. International Journal of Remote Sensing, 28 (15), 3255-3271.

Tavakoli, M. and De Smedt, F., 2013. Validation of soil moisture simulation with a distributed hydrologic model (WetSpa). Environment and Earth Science, 69, 739-747. 
635

636

637

638

639

640

641

642

643

644

645

646

647

648

649

650

651

652

653

654

655

Vargas-Pineda, O. I., Trujillo-González, J. M. \& Torres-Mora, M. A. 2020. Supply-Demand of Water Resource of a Basin With High Anthropic Pressure: Case Study Quenane-Quenanito Basin in Colombia. Air, Soil and Water Research 13, 1178622120917725.

Visessri, S. and McIntyre, N., 2016. Regionalisation of hydrological responses under land-use change and variable data quality. Hydrological Sciences Journal, 61(2), 302-320.

Wagner, P., Kumar, S. and Schneider, K., 2013. An assessment of land use change impacts on the water resources of the Mula and Mutha Rivers catchment upstream of Pune, India. Hydrological Earth System Science, 17, 2233-2246.

Wang, C., Zhao, C., Xu, Z., Wang, Y. \& Peng, H. 2013. Effect of vegetation on soil water retention and storage in a semi-arid alpine forest catchment. Journal of Arid Land 5(2), 207-219.

Wang, H. and Chen, Y., 2019. Identifying key hydrological processes in highly urbanized watersheds for flood forecasting with a distributed hydrological model. Water, 11(8), 1641.

Wang, K., Zhang, Q., Chen, Y.D., Singh, V.P., 2015. Effects of land-use/cover change on hydrological processes using a GIS/RS-based integrated hydrological model: case study of the East River, China, Hydrological Sciences Journal, 60(10), 1724-1738.

Wang, Z., Batelaan, O. and De Smedt, F., 1996. A distributed model for Water and Energy Transfer between Soil, Plants and Atmosphere. Physical and Chemical Earth, 21, 189-193.

Weng, Q., 2002. Land use change analysis in the Zhujiang delta of China using satellite remote sensing, GIS and stochastic modeling. Journal of Environmental Management, 64, 273-284.

Yang, X., Zheng, X.Q., Lv, L.N., 2012. A spatiotemporal model of land use change based on ant colony optimization, Markov chain and cellular automata. Ecological Modeling, 233, 11-19. 
656 657 658 659 660 661 662 663 664 665 666 667 668 669 670

\section{Figure Captions}

672 Figure 1. Location of the study area in Iran (a) and Golestan Province (b), and digital elevation 673 model of the Ziarat Catchment (c).

674

675 Figure 2. Urban areas of the Ziarat Catchment.

676

677 Figure 3. Flowchart describing the methodology used in this study.

Zakerinejad, R. and Maerker, M., 2015. An integrated assessment of soil erosion dynamics with special emphasis on gully erosion in the Mazayjan Basin, southwestern Iran. Natural Hazards, $79,25-50$.

Zeinivand, H., 2015. Comparison of interpolation methods for precipitation fields using the physically based and spatially distributed model of river runoff on the example of the Gharesou basin, Iran. Russian Meteorology and Hydrology, 40 (7), 480-488.

Zhang, L., Nan, Z., Xu, Y. and Li, S., 2016. Hydrological impacts of land use change and climate variability in the headwater region of the Heihe River Basin, Northwest China. PLoS ONE, 11 (6), 1-25.

Zheng, Y., Zhang, M. and Wu, B., 2016. Using high spatial and temporal resolution data blended from SPOT-5 and MODIS to map biomass of summer maize. In: Agro-geoinformatics (Agrogeoinformatics), 2016 Fifth International Conference on IEEE, pp. 1-5. 
679 Figure 4. Digital elevation model (a) and soil texture (b) maps of the Ziarat Catchment.

680

681 Figure 5. Land use maps of the Ziarat Catchment for 2001 and 2016.

682

683 Figure 6. Land use map of the Ziarat Catchment for 2032.

684

685 Figure 7. Graphical comparison between observed and calculated hourly flow data for March 6862010 from the calibration period.

687 
Table 1. Hydrometeorological station characteristics

\begin{tabular}{cccccc}
\hline \multirow{2}{*}{ ID } & \multirow{2}{*}{ Station } & Type of hourly data & Herght & \multirow{2}{*}{ Longitude } & Latitude \\
\hline $12-212$ & Abgir & Precipitation & 950 & $54^{\circ} 28^{\prime} 23.68^{\circ}$ & $36^{\circ} 42^{\prime} 1.23^{\prime \prime}$ \\
$12-024$ & Naharkhoran & Precipitation & 500 & $52^{\circ} 43^{\prime} 48.32^{\prime \prime}$ & $36^{\circ} 29^{\prime} 41.58^{\prime \prime}$ \\
$12-043$ & Naharkhoran & Discharge & 330 & $54^{\circ} 27^{\prime} 60.00^{\prime \prime}$ & $36^{\circ} 44^{\prime} 0.01^{\prime \prime}$ \\
$12-215$ & Abgir & Temperature and & 950 & $54^{\circ} 28^{\prime}=\underline{\underline{50.53}}$ & $36^{\circ} 42^{\prime} 38.89^{\prime \prime}$ \\
\hline
\end{tabular}

Table 2. Evaluation results of land use classification.

\begin{tabular}{|c|c|c|c|c|c|}
\hline Year & $\begin{array}{l}\text { Land use class } \\
\left(\mathrm{km}^{2}\right)\end{array}$ & $\begin{array}{l}\text { Producer } \\
\text { accuracy }\end{array}$ & $\begin{array}{c}\text { User } \\
\text { accuracy }\end{array}$ & $\begin{array}{c}\text { Overall accuracy } \\
(\%)\end{array}$ & $\begin{array}{c}\text { Kappa } \\
\text { coefficient }\end{array}$ \\
\hline \multirow{4}{*}{2001} & Forest & 96.83 & 98.95 & \multirow{4}{*}{89.4} & \multirow{4}{*}{0.77} \\
\hline & Urban & 72.57 & 32.07 & & \\
\hline & Agriculture & 74.59 & 45.98 & & \\
\hline & Grassland & 96.53 & 96.53 & & \\
\hline \multirow{4}{*}{2016} & Forest & 94.57 & 95.96 & \multirow{4}{*}{89.4} & \multirow{4}{*}{0.81} \\
\hline & Urban & 73.65 & 67.55 & & \\
\hline & Agriculture & 67.82 & 72.71 & & \\
\hline & Grassland & 9.72 & 88.87 & & \\
\hline
\end{tabular}

Table 3. Transition probability for converting land use classes into another.

\begin{tabular}{ccccc}
\hline Land use class & Urban & Agriculture & Forest & Grassland \\
\hline Forest & 0.30 & 0.00 & 0.68 & 0.02 \\
Agriculture & 0.88 & 0.10 & 0.00 & 0.02 \\
Urban & 0.59 & 0.07 & 0.01 & 0.32 \\
Grassland & 0.08 & 0.20 & 0.24 & 0.48 \\
\hline
\end{tabular}


Table 4. Total area and percentage of change of each land use class among different years.

\begin{tabular}{ccccccc}
\hline & \multicolumn{2}{c}{ ha } & $\%$ & \multicolumn{2}{c}{2001 to 2032} \\
\cline { 2 - 7 } Land use & 2001 & 2016 & 2001 to 2016 & ha & $\%$ \\
& & & & & \\
\hline Forest & 7562 & 6689 & -11.54 & 5046 & -33.27 \\
Urban & 53 & 932 & +1658.49 & 2540 & +4692.45 \\
Agriculture & 594 & 581 & -2.18 & 931 & -56.73 \\
Range land & 1371 & 1378 & -0.50 & 1068 & -22.10 \\
\hline
\end{tabular}

Table 5. Introduction of land use change maps.

\begin{tabular}{ll}
\hline Land use map & Introduction \\
\hline 1 & 2001 (Past condition) \\
2 & 2016 (Current condition) \\
3 & 2032 (Future condition) \\
\hline
\end{tabular}

Table 6. Comparison of changes in simulated hydrological parameters parallel to the land use changes in the Ziarat Catchment.

\begin{tabular}{lcclcl}
$\begin{array}{l}\text { Hydrological } \\
\text { parameters }\end{array}$ & 2001 & 2016 & $\begin{array}{l}\text { \% of change } \\
(2001-2016)\end{array}$ & 2032 & $\begin{array}{l}\text { \% of change } \\
(2001-2032)\end{array}$ \\
\hline Peak discharge $\left(\mathrm{m}^{3} / \mathrm{s}\right)$ & 3.01 & 3.82 & +26.91 & 4.73 & +57.11 \\
Flow time $(\mathrm{h})$ & 6.09 & 5.82 & +4.43 & 4.28 & -29.72 \\
Flow velocity $\left(\mathrm{m} / \mathrm{s}^{2}\right)$ & 0.07 & 0.09 & +24.63 & 2.79 & +39.43 \\
\hline
\end{tabular}

Table 7. Comparison of changes in simulated flow components to each land use change in the Ziarat Catchment

\begin{tabular}{cccccc}
\hline Flow components & 2001 & 2016 & $\begin{array}{c}\text { \% of change } \\
(2001-2016)\end{array}$ & 2032 & $\begin{array}{c}\text { \% of change } \\
(2001-2032)\end{array}$ \\
\hline Total runoff(R) & 325.00 & 333.4 & +2.58 & 345.50 & +6.30 \\
Surface runoff (SR) & 3.10 & 4.60 & +48.38 & 5.70 & +83.87 \\
Interflow runoff(IR) & 16.00 & 16.40 & +2.50 & 16.80 & +5.00 \\
Groundwater runoff (GR) & 305.90 & 312.50 & +2.15 & 322.90 & +5.55 \\
\hline
\end{tabular}



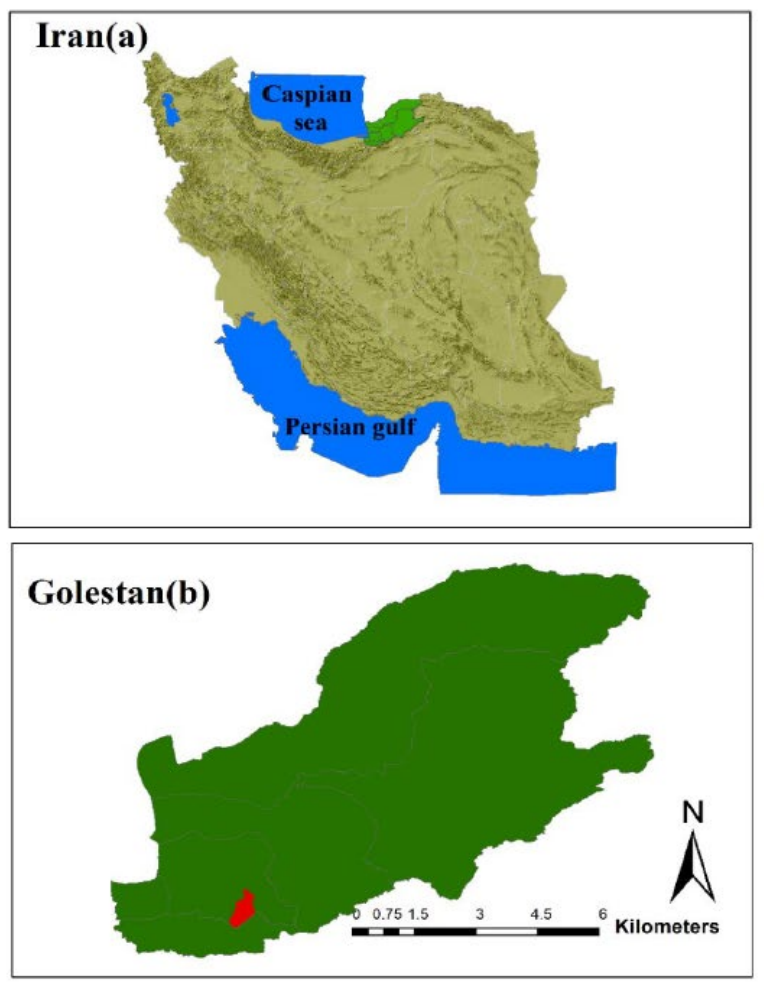

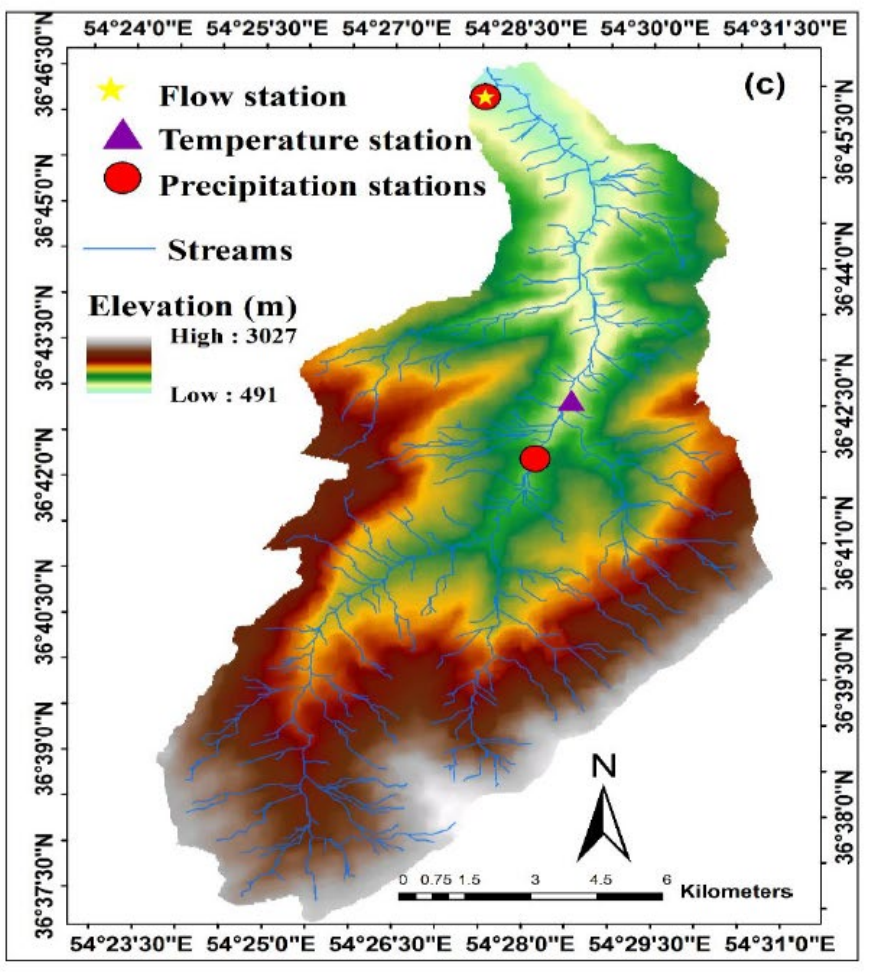

Figure 1. Location of the study area in Iran (a) and Golestan Province (b), and digital elevation model of the Ziarat Catchment (c). 

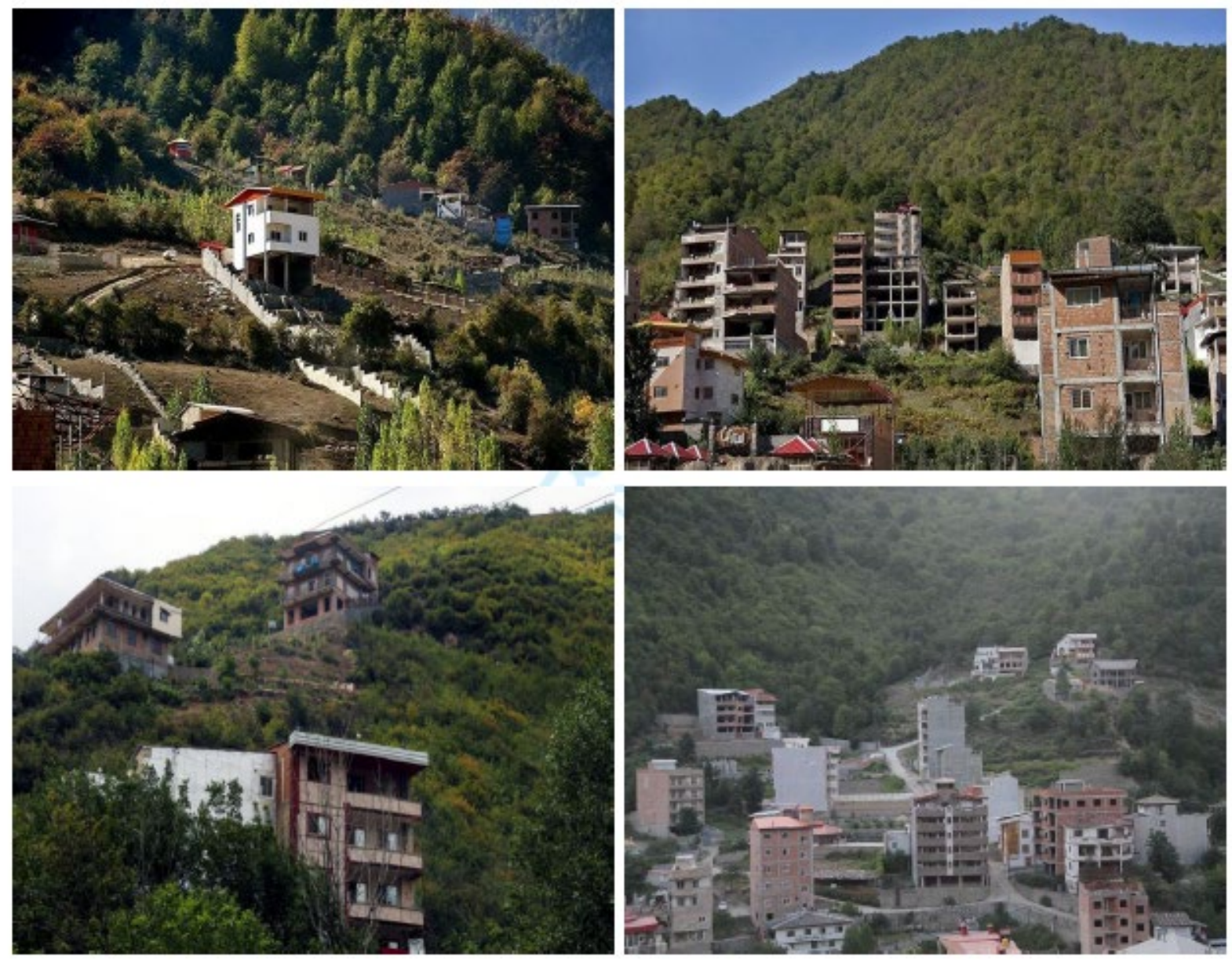

Figure 2 Urban areas of the Ziarat catchment 


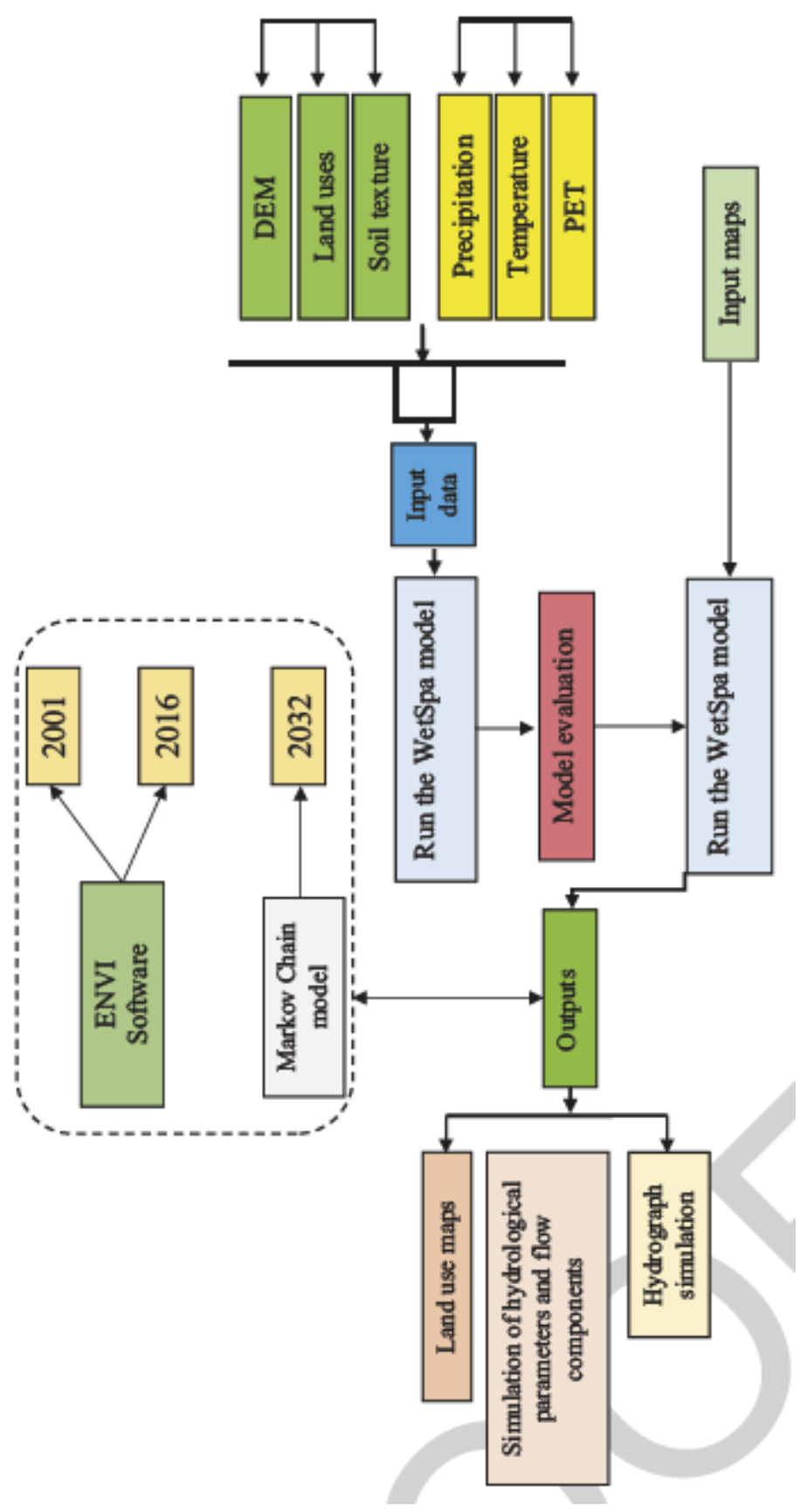

Figure 3. Flowchart describing the methodology used in this study 
Figure 3.
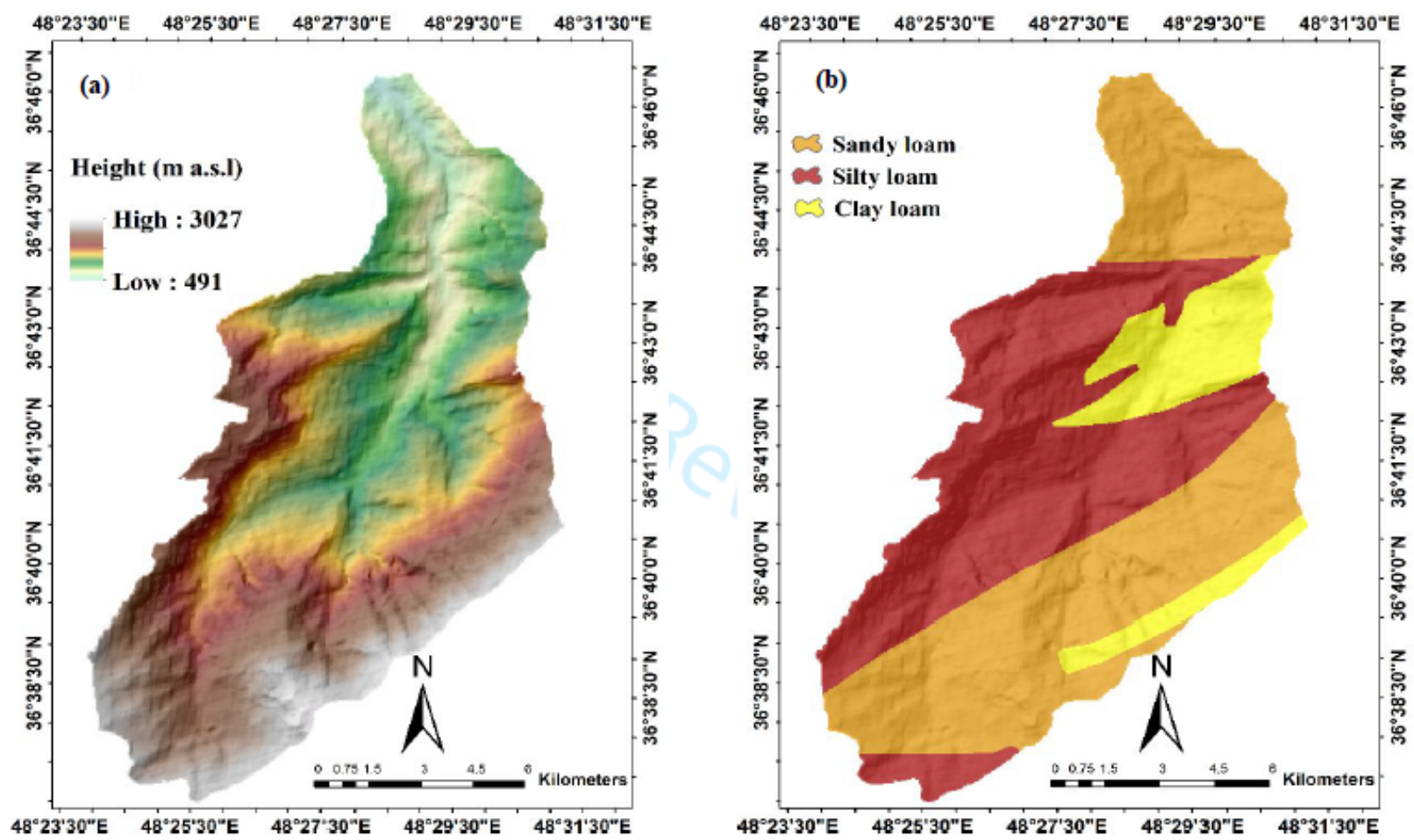

Figure 4. Digital elevation model (a) and soil texture (b) maps of the Ziarat Catchment 

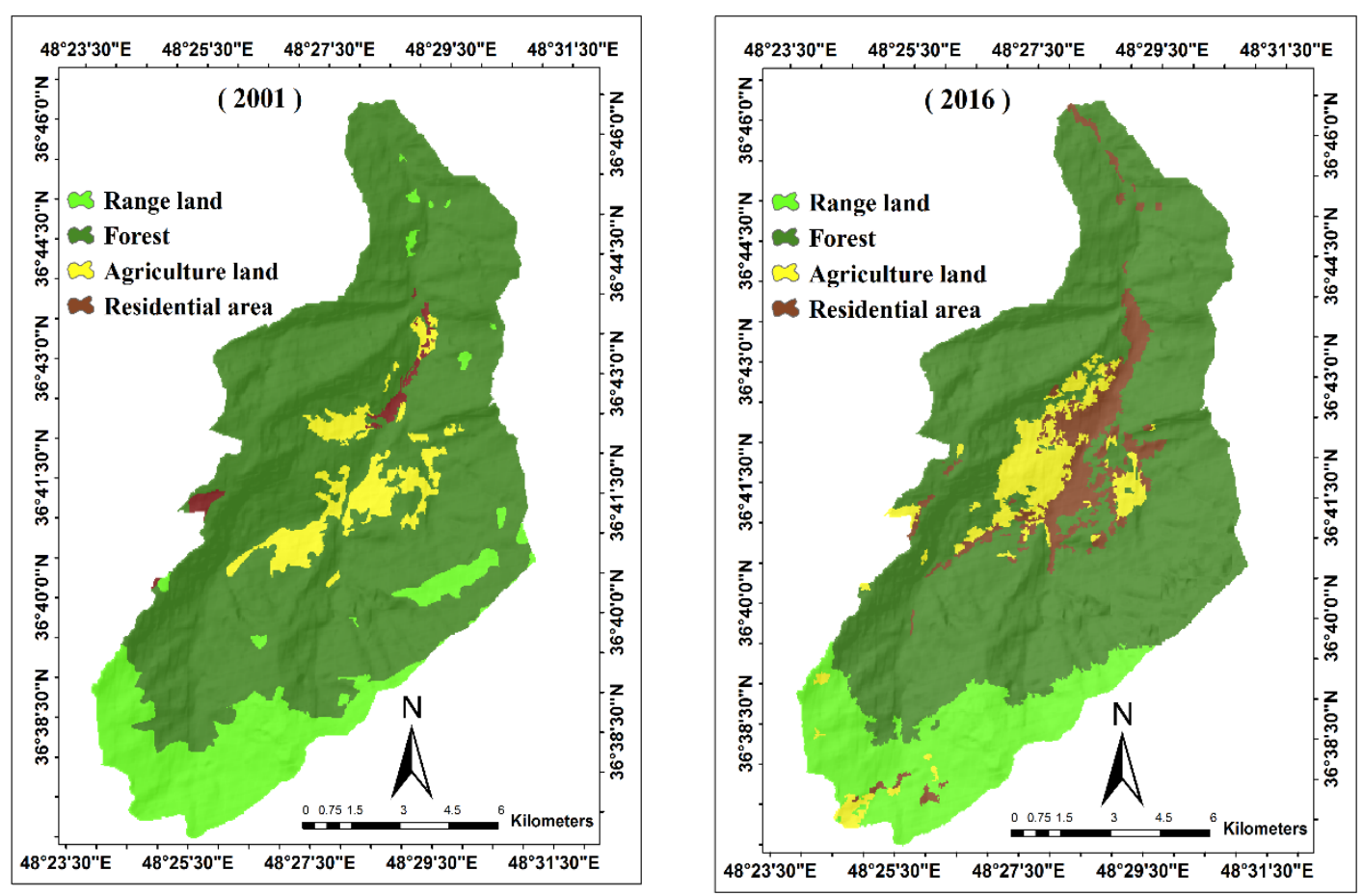

Figure 5. Land use map of the Ziarat watershed for 2001 and 2016 


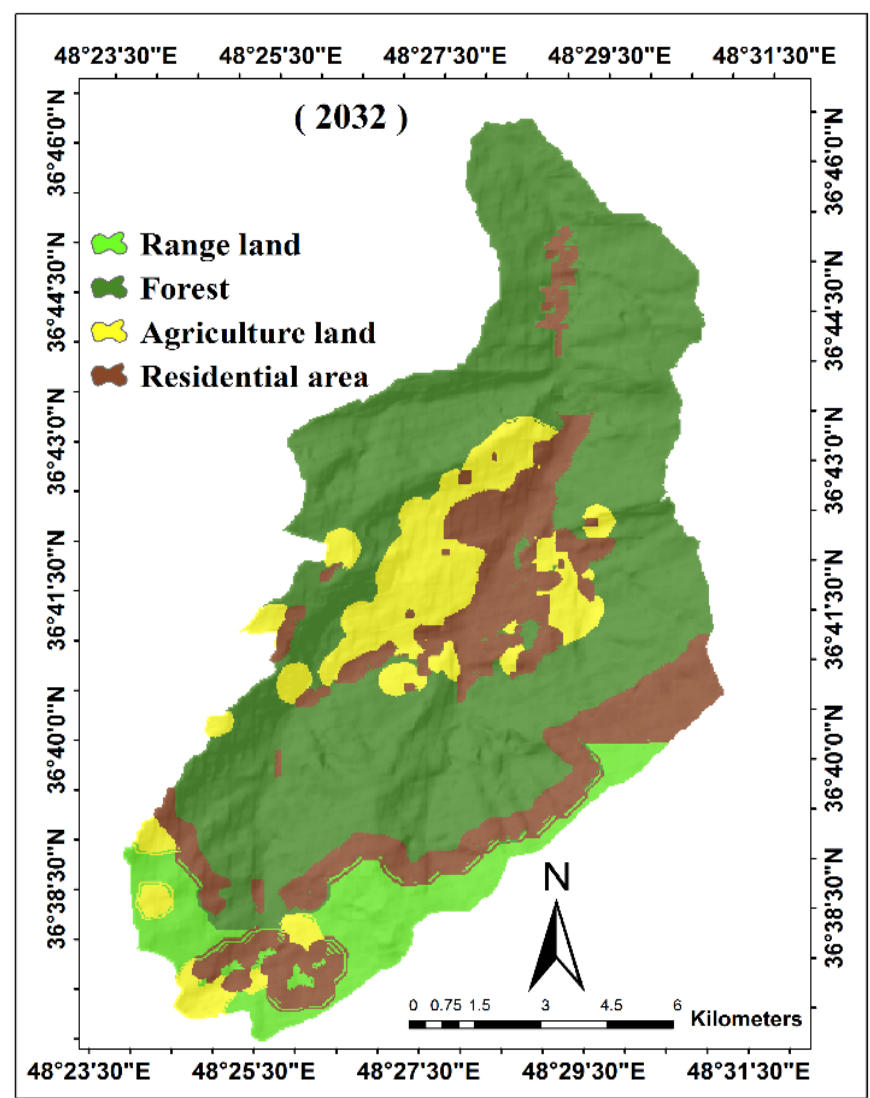

Figure 6. Land use map of the Ziarat watershed for 2032 


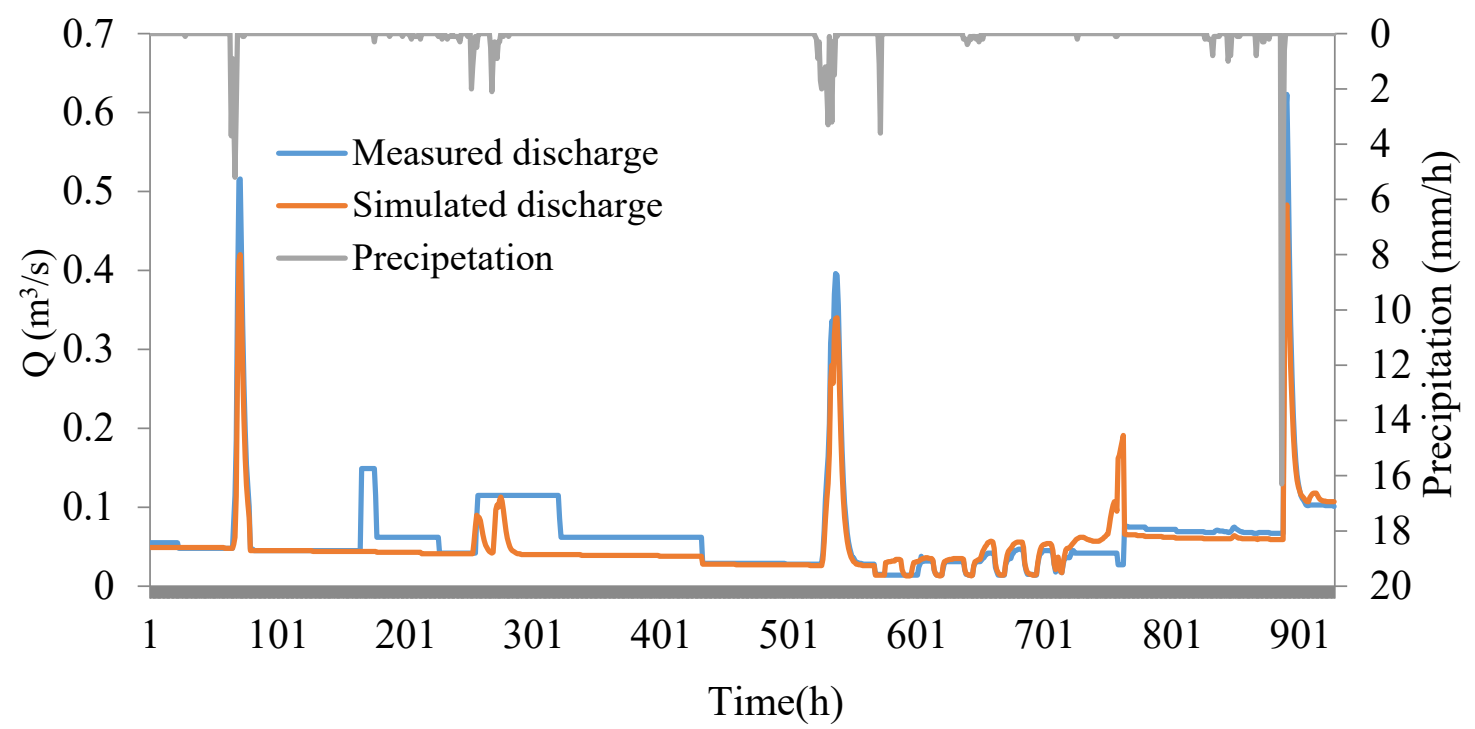

Figure 7. Graphical comparison between observed and calculated hourly flow data for March 6542010 from the calibration period. 